\title{
Simulasi Model Sistem Kerja Pada Departemen Injection Untuk Meminimasi Waktu Work-In-Process
}

\author{
Ong Andre Wahyu Riyanto ${ }^{1}$
}

\begin{abstract}
The smooth process of manufacturing and production requires the operating machine in good condition. If the machine breakdown happened then the production process will be stopped, the production target was not achieved, due date can not be met. So that the costumer will become dissatisfied, and so on. The purpose of this study is to evaluate the work system of the injection department. Also reduce the waiting time for repair the broken machine at existing production system. This study propose the method of modeling and simulation for examine the working system object using the simulation software of Arena. Based on the experiment, it can be seen that the simulation model repair in scenario-1 gives impact on the level of activity of technicians up to $20.2 \%$ without any reduction in processing time. From the simulation model, the scenario-2 gives impact of changes in the levels of technicians activity decline by $5.56 \%$ and can decrease the processing time up to $8.33 \%$.
\end{abstract}

Keywords. Arena software, manufacturing, modeling, simulation.

\begin{abstract}
Abstrak. Kelancaran proses manufaktur dan hasil produksi yang berkualitas memerlukan dukungan pengoperasian mesin selalu dalam kondisi yang baik. Jika kerusakan mesin terjadi maka proses produksi akan berhenti, target produksi tidak tercapai, tanggal jatuh tempo tidak dapat dipenuhi. Sehingga pelanggan akan menjadi tidak puas dan sebagainya. Tujuan penelitian ini adalah untuk mengevaluasi sistem kerja pada Departemen Injection dan mengurangi waktu tunggu terhadap perbaikan mesin yang rusak pada sistem produksi yang ada. Penelitian menggunakan metode pemodelan dan simulasi untuk menguji obyek sistem kerja dengan menggunakan perangkat lunak simulasi Arena. Berdasarkan percobaan, dapat diketahui bahwa perbaikan model simulasi dalam skenario-1 memberi dampak pada tingkat aktivitas teknisi hingga 20,2 \% tanpa adanya penurunan waktu proses. Sedangkan dari model simulasi, skenario-2 memberikan dampak perubahan dalam tingkat penurunan aktivitas teknisi sebesar 5,56 \% dan mengurangi waktu pemrosesan hingga 8,33\%.
\end{abstract}

Kata kunci: software Arena, manufaktur, pemodelan, simulasi.

\section{Pendahuluan}

Jaminan kelancaran proses manufaktur dan hasil produksi yang berkualitas memerlukan dukungan mesin produksi yang selalu dalam kondisi operasi yang baik. Pada saat mesin produksi mengalami kegagalan operasi, maka akan mengakibatkan proses produksi terhenti, target yang ditetapkan tidak tercapai, due date yang telah dijanjikan kepada konsumen tidak dapat dipenuhi. Sehingga konsumen akan menjadi tidak puas dan seterusnya.

Salah satu upaya untuk menjamin ketersediaan

\footnotetext{
${ }^{1}$ Ong Andre Wahyu Riyanto, Prodi Teknik Industri, Fakultas Teknik, Universitas Wijaya Putra, Jl. Raya

Benowo No: 1-3, Surabaya (email: ongandre@uwp.ac.id)
}

Diajukan: 20-03-2016 Disetujui: 20-06-2016 mesin yang selalu dalam kondisi siap beroperasi adalah menjaga ketersediaan teknisi mesin yang memadai berdasarkan frekuensi kerusakan mesin. Pada kenyataannya, jumlah ketersediaan teknisi yang seharusnya dimiliki oleh sebuah perusahaan manufaktur cukup sulit ditentukan mengingat aktifitas teknisi didasarkan pada terjadinya kerusakan mesin. Dimana kejadian kerusakan mesin itu sendiri cukup sulit diprediksi kapan dan apa yang akan rusak.

Demikian pula yang terjadi di PT. X, sebuah perusahaan manufaktur di Departemen Injection yang memproduksi produk furniture berbahan baku utama biji plastik dengan produk utama kursi plastik, kursi perkantoran, dan filling kabinet plastik. Produksi menggunakan mesin injection plastic molding. Sistem produksinya job order dan continous order. Produk filling kabinet plastik menggunakan sistem produksi continous order dengan kapasitas produksi rata-rata 
sebanyak 10.000 unit per bulan. Sedangkan produk kursi plastik, kursi perkantoran menggunakan sistem produksi job order. Produk filling kabinet sendiri terdiri dari berbagai macam tipe, mulai dari bee cabinet, butterfly cabinet, twin bee cabinet, avanza cabinet, new cabinet, big bee cabinet dan masih banyak lagi tipe produk yang mengharuskan seringnya dilakukan pergantian cetakan (mold).

Karena cukup sulit memprediksi waktu antar pergantian cetakan (mold), waktu antar kerusakan mesin serta waktu yang dibutuhkan untuk menyelesaikan pekerjaan tersebut, maka mengakibatkan sulit dalam menentukan jumlah ketersediaan teknisi yang harus dimiliki oleh departemen injection PT. X. Teknisi adalah personil yang bertugas dan bertanggung jawab terhadap perbaikan kerusakan mesin dan pergantian cetakan (mold). Saat ini di lantai produksi Departemen Injection PT. X jumlah teknisi yang semula adalah 2 orang ditambah menjadi 4 orang. Karena dirasa banyak mesin yang berhenti produksi karena menunggu perbaikan. Dari jumlah tersebut, dengan alasan yang sama perusahaan merencanakan untuk menambah jumlah teknisi lagi menjadi 5 orang.

Dari latar belakang di atas dapat dirumuskan permasalahan yang terjadi di Departemen Injection PT. X adalah ketersediaan jumlah teknisi mesin injection plastic molding yang ideal untuk menjamin kelancaran proses produksi. Tujuan penelitian ini adalah mengidentifikasi ketersediaan jumlah teknisi untuk mengantisipasi lamanya mesin menunggu perbaikan kerusakan ketika proses produksi sedang berlangsung.

Dalam penelitian ini pembahasan dilakukan dengan mensimulasikan sistem kerja di Departemen Injection PT. X dengan tujuan untuk mengevaluasi sistem kerja teknisi dalam mengantisipasi lamanya mesin yang rusak menunggu perbaikan pada sistem produksi yang ada. Metode simulasi dilakukan dengan menggunakan bantuan aplikasi perangkat lunak simulasi Arena.

Asumsi pengamatan dan pengambilan data dalam penelitian ini adalah: selama 6 hari kerja (jam kerja teknisi 08.00 - 16.00 WIB), jumlah mesin sebanyak 15 unit, dan kapasitas produksi konstan. Untuk memperbaiki suatu sistem diperlukan pengumpulan data-data dari sistem nyata (real system) yang kemudian digunakan untuk mengestimasi parameter input dan memperoleh distribusi probabilitas variabel acak yang diambil dan digunakan pada model sistem.

Metode simulasi telah banyak digunakan untuk memperbaiki kinerja suatu sistem produksi manufaktur maupun sistem pelayanan/jasa. Kajian simulasi ke atas sistem pemuatan dan pemunggahan gudang menggunakan Arena (Liong \& Loo, 2009). Analisis bottle neck dengan pendekatan simulasi Arena pada produk sarung tenun ikat tradisional (Wahyani \& Ahmad, 2009). Model simulasi kinerja produksi teh untuk minimisasi work-in-process (Wibowo \& Ramadian, 2010). Simulasi teknik penanganan material sistem produksi secara manual dan otomatis berbasis automatic guided vehicle (Sulistyono \& Sudiarso, 2013).

Simulasi adalah suatu metode yang penting karena keunggulan dalam memperbaiki kinerja suatu sistem tanpa mengganggu kelancaran kerja sistem nyata (real system). Sebuah model simulasi dikembangkan untuk mempelajari kerja sistem yang berkembang dari waktu ke waktu. Teknik simulasi diskrit adalah salah satu model simulasi pengoperasian sistem sebagai urutan peristiwa diskrit (Sharma, 2015).

\section{Metodologi}

Langkah-langkah yang ditempuh dalam menyelesaikan penelitian ini ditunjukkan pada diagram alir penelitian, seperti pada Gambar 1.

\section{HASIL DAN PEMBAHASAN}

\section{Kondisi real system}

Departemen Injection PT. X memiliki mesin injection plastic molding sebanyak 15 unit yang terdiri dari 5 mesin skala kecil dan 10 mesin skala besar, serta sebuah crane dengan kekuatan maksimal 5 ton yang melingkupi semua mesin produksi. Mesin yang digolongkan dalam mesin skala kecil adalah mesin yang mempunyai kekuatan pressure antara 105 ton sampai dengan 180 ton. Masing-masing mesin ini dilengkapi dengan katrol manual dalam penggantian cetakan (mold) dan tidak menggunakan crane. Sedangkan mesin yang digolongkan dalam mesin skala besar adalah mesin yang mempunyai kekuatan pressure antara 260 ton sampai dengan 800 ton. Masing-masing mesin ini tidak dilengkapi dengan katrol manual, tetapi harus 


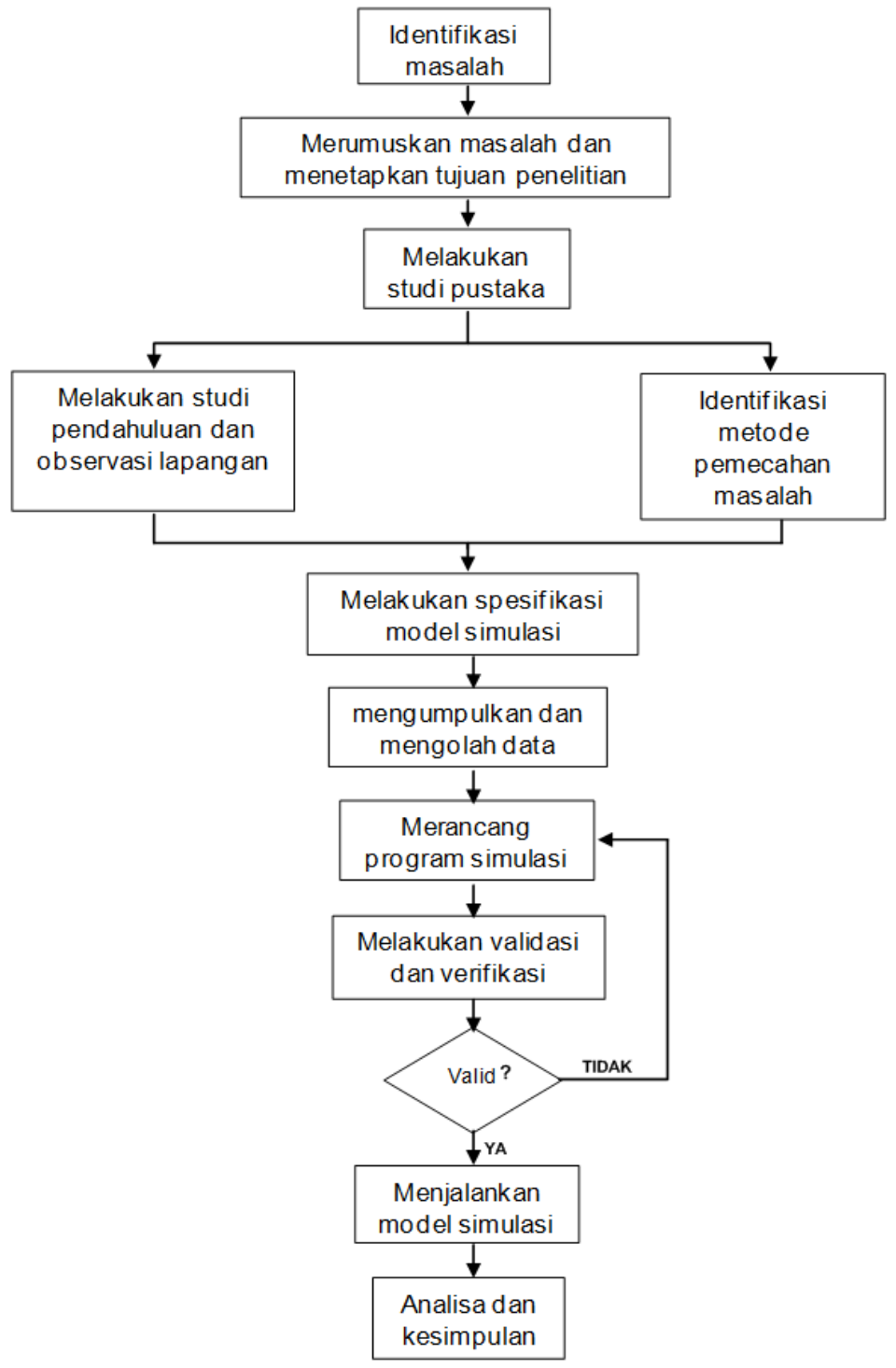

Gambar 1. Diagram alir penelitian

menggunakan crane dalam penggantian cetakan ( mold).

Departemen Injection PT. X mempunyai 4 orang teknisi yang terbagi menjadi 2 server, yaitu server-1 dan server-2. Server 1 terdiri dari 3 orang teknisi yang disebut sebagai teknisi-1, teknisi-2, dan teknisi-3. Sedang server-2 terdiri dari 1 orang teknisi yang akan kita sebut sebagai teknisi-4. Server-1 bertugas mengerjakan semua kegiatan yang berhubungan dengan mesin injection kecuali untuk pengerjaan elektrik dan elektronik yang merupakan tugas atau tanggung jawab dari server-2.

Mesin yang berhenti produksi karena kerusakan atau penggantian cetakan (mold), operator mesin juga diwajibkan membantu teknisi dalam menangani mesin tersebut. Sehingga dalam melakukan semua tugasnya, seorang teknisi tidak membutuhkan bantuan teknisi yang lain meski terdapat beberapa teknisi dalam kondisi menganggur (idle).

\section{Elemen sistem}

Bagian ini menguraikan mengenai elemenelemen yang membentuk sistem yang nantinya akan ditransformasikan dalam model simulasi. Adapun elemen-elemen pembentuk sistem di sini adalah:

1. Entitas (entity), entitas di sini adalah suatu bentuk kerusakan mesin atau pergantian 
cetakan yang harus diproses oleh resources yang dalam kasus ini disebut sebagai teknisi dan crane. Dalam pemodelan simulasi ini terdapat beberapa entititas yang terbagi berdasarkan jenis kegiatan yang harus dikerjakan oleh teknisi. Entititas di sini sengaja dibagi menjadi beberapa kelompok karena adanya perbedaan waktu proses, waktu antar kedatangan, serta perbedaan dalam perlakuan entititas tersebut. Adapun beberapa entititas tersebut adalah sebagai berikut:

a. Pergantian cetakan besar, proses pergantian cetakan besar ini memerlukan bantuan crane. Untuk proses pengerjaannya dibutuhkan 1 orang teknisi.

b. Service cetakan, meliputi perbaikan dan perawatan cetakan yang berukuran besar. Proses pengerjaanya membutuhkan bantuan crane.

c. Pergantian cetakan kecil, pergantian cetakan yang dilakukan oleh 1 orang teknisi yang dalam proses pengerjaanya menggunakan bantuan katrol manual namun apabila crane dalam keadaan menganggur (idle), maka proses pengerjaannya dapat memanfaatkan crane. Sehingga dapat meringankan pekerjaan teknisi serta dapat mempercepat $10 \%$ dari waktu proses menggunakan katrol manual.

d. Mekanik, adalah semua pekerjaan yang berhubungan dengan service mesin injection kecuali mengenai elektronik dan elektriknya. Misalnya; perbaikan valve, perbaikan pintu mesin, perbaikan lubrication oil pump, dan lain-lain. Karena dalam service cetakan kecil tidak

Tabel 1. Data interarrival time pergantian cetakan (mold) besar

\begin{tabular}{cccccccccc}
\hline No & $\begin{array}{c}\text { Interarrival } \\
\text { time } \\
\text { (menit) }\end{array}$ & No & $\begin{array}{c}\text { Interarrival } \\
\text { time } \\
\text { (menit) }\end{array}$ & No & $\begin{array}{c}\text { Interarrival } \\
\text { time } \\
\text { (menit) }\end{array}$ & No & $\begin{array}{c}\text { Interarrival } \\
\text { time } \\
\text { (menit) }\end{array}$ & No & $\begin{array}{c}\text { Interarrival } \\
\text { time } \\
\text { (menit) }\end{array}$ \\
\hline 1 & 354 & 11 & 95 & 21 & 276 & 31 & 223 & 41 & 42 \\
2 & 266 & 12 & 411 & 22 & 673 & 32 & 210 & 42 & 124 \\
3 & 789 & 13 & 288 & 23 & 512 & 33 & 606 & 43 & 466 \\
4 & 686 & 14 & 658 & 24 & 539 & 34 & 1009 & 44 & 2073 \\
5 & 208 & 15 & 830 & 25 & 379 & 35 & 580 & 45 & 721 \\
6 & 475 & 16 & 485 & 26 & 433 & 36 & 988 & 46 & 536 \\
7 & 455 & 17 & 572 & 27 & 250 & 37 & 802 & 47 & 212 \\
8 & 130 & 18 & 1081 & 28 & 67 & 38 & 8 & & \\
9 & 125 & 19 & 263 & 29 & 200 & 39 & 547 & & \\
10 & 421 & 20 & 480 & 30 & 502 & 40 & 1195 & & \\
\hline
\end{tabular}

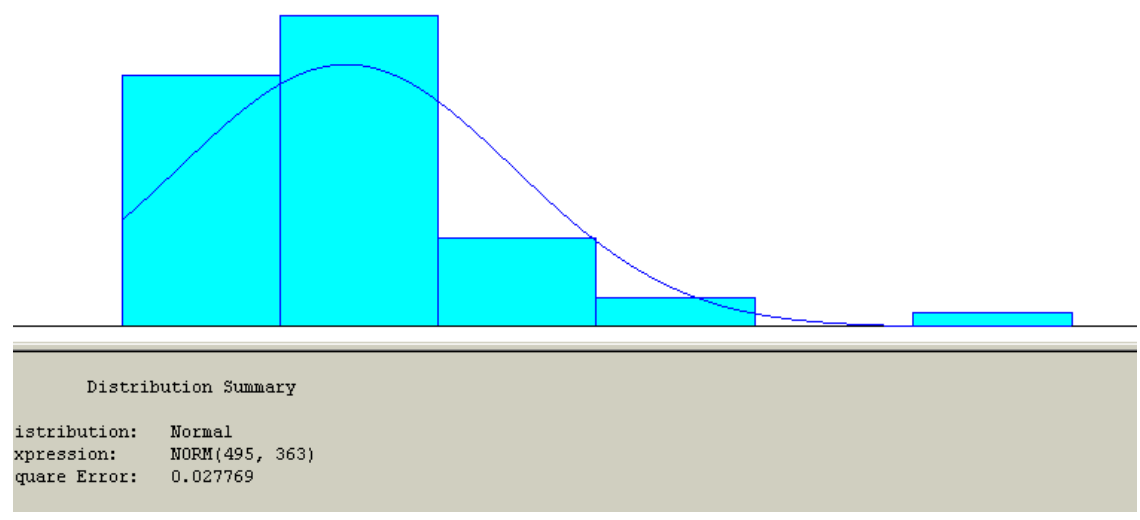

Gambar 2. Data interarrival time pergantian cetakan (mold) besar 
membutuhkan crane yang dapat memicu terjadinya antrian, maka kegiatan ini dimasukan dalam kegiatan mekanik.

e. Tugas luar, meliputi perbelanjaan alat-alat atau komponen mesin injection dan perbaikan suatu komponen mesin injection yang menggunakan bantuan jasa luar.

f. Perbaikan pendingin, meliputi semua kegiatan yang berhubungan dengan air pendingin mesin injection. Misalnya; saluran air pendingin bocor, saluran air pendingin buntu, dan lain-lain.

g. Setting, mesin injection ini dilengkapi dengan sistem komputer khusus yang digunakan dalam set-up proses produksi. Set-up ini dilakukan karena adanya kekurangsempurnaan produk yang dihasilkan oleh mesin injection. Misalnya; adanya kelebihan atau kekurangan berat produk, pengaturan cycle time, pengaturan kekuatan pressure, dan lain-lain. Setting ini merupakan kegiatan yang harus dilakukan oleh server-1 namun seringkali ditengahtengah pengerjaan, kegiatan ini dilimpahkan pada server-2 karena server-1 melihat ada masalah yang diluar kemampuannya atau masalah tersebut sulit ditangani.

Tabel 3. Hasil pengujian data service time pada server-1

\begin{tabular}{clll}
\hline No. & Entity & Distribution & Expression \\
\hline 1 & Pergantian matras besar & Beta & $84.5+96 * \operatorname{BETA}(0.824,1.21)$ \\
2 & Service matras & Beta & $45+105 * \operatorname{BETA}(1.06,1.27)$ \\
3 & Pergantian matras kecil & Beta & $59.5+61 * \operatorname{BETA}(0.581,0.846)$ \\
4 & Mekanik & Erlang & $30+\operatorname{ERLA}(69,1)$ \\
5 & Tugas luar & Normal & NORM $(105,19.6)$ \\
6 & Perbaikan pendingin & Beta & $9.5+81 * \operatorname{BETA}(0.374,0.922)$ \\
7 & Setting & Gamma & $6.5+\operatorname{GAMM}(8.7,1.4)$ \\
8 & Setting sebelum server 2 & Beta & $9.5+51 * \operatorname{BETA}(0.384,0.539)$ \\
9 & Kerusakan sebelum server 2 & Beta & $3.5+27 * \operatorname{BETA}(0.867,1.77)$ \\
\hline
\end{tabular}

Tabel 4. Hasil pengujian data service time pada server-2

\begin{tabular}{clll}
\hline No. & Entity & Distribution & Expression \\
\hline 1 & Pergantian matras besar & - & - \\
2 & Service matras & - & - \\
3 & Pergantian matras kecil & - & - \\
4 & Mekanik & - & - \\
5 & Tugas luar & - & - \\
6 & Perbaikan pendingin & - & - \\
7 & Setting & Beta & $29.5+91 * \operatorname{BETA}(0.363,0.341)$ \\
8 & Elektrik & Exponential & $15+\operatorname{EXPO}(59.6)$ \\
9 & Elektronik & Erlang & $30+\operatorname{ERLA}(150,1)$ \\
\hline
\end{tabular}

Tabel 5. Kriteria performansi sistem

\begin{tabular}{|c|c|c|c|}
\hline No & Kriteria & Deskripsi & Ekspresi \\
\hline 1 & Utilitas & Meliputi utilitas resources & Maximum \\
\hline 2 & Waktu proses & $\begin{array}{l}\text { Waktu yang dibutuhkan untuk menyelesaikan } \\
\text { suatu entity }\end{array}$ & Minimum \\
\hline 3 & Qиеие time & $\begin{array}{l}\text { Meliputi waktu yang dibutuhkan suatu entity } \\
\text { untuk menunggu diproses }\end{array}$ & Minimum \\
\hline
\end{tabular}


h. Elektrik, meliputi semua kegiatan yang berhubungan dengan kelistrikan mesin injection. Misalnya; perbaikan hyper dryer, perbaikan konsleting, dan lain-lain.

i. Elektronik, meliputi semua kegiatan yang berhubungan dengan elektronik dari mesin injection. Seperti; perbaikan komputer mesin injection, perbaikan thermo control, perbaikan limit switch, dan lain-lain.

2. Process, process di sini adalah suatu perlakuan resources terhadap entity-entity yang datang. Tiap-tiap entity mendapatkan perlakuan yang berbeda dari resources. Misalnya; dibutuhkan crane untuk mengganti cetakan besar, server-1 tidak akan mengerjakan kerusakan yang berhubungan dengan elektrik atau elektronik, dan lainnya.

3. Resources, recources di sini yaitu serverserver dan suatu alat yang dinamakan crane yang memproses entity-entity yang masuk. Server disini dibagi menjadi 2 macam yaitu server-1 dan server-2. Untuk masing-masing anggota dari server serta tugasnya telah diterangkan di atas. Dalam masing-masing proses, hanya dibutuhkan 1 orang teknisi karena sudah ada 1 orang operator yang membantu teknisi yang sibuk. Meskipun ada satu teknisi yang sibuk sedangkan yang lain menganggur (idle), maka teknisi yang idle tersebut tidak membantu teknisi yang sibuk.

\section{Pengolahan data}

Pengolahan lebih lanjut menggunakan metode statistik dipersiapkan sebagai input dalam model simulasi. Tahap ini meliputi uji distribusi yang sesuai dengan karakteristik data. Pengujian distribusi data dilakukan dengan bantuan software input anayzer pada aplikasi perangkat lunak Arena versi 3.0. Tabel 1menunjukkan hasil uji distribusi data waktu antar kedatangan pergantian cetakan (mold) besar.

Bentuk distribusi data pada Tabel 1 ditunjukkan pada Gambar 2. Dari distribution summary pada Gambar 2 dapat diketahui bahwa data yang dimasukan berdistribusi normal dengan expression Norm(495, 363).

Hasil pengolahan data dari masing-masing entity dapat dilihat pada Tabel 2 .

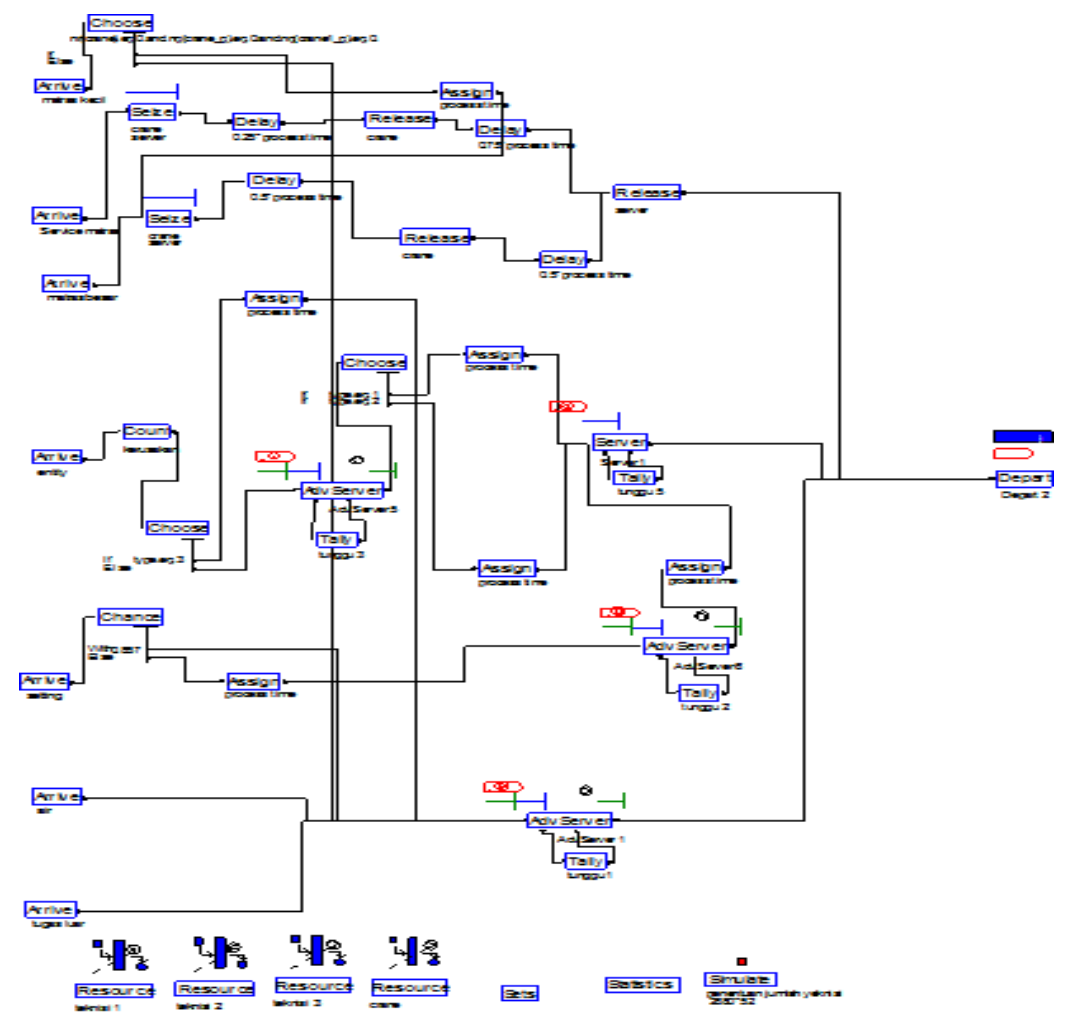

Gambar 3. Model real system Departemen Injection 
Waktu yang dibutuhkan untuk pengerjaan (service time) juga diuji jenis distribusinya dengan cara yang sama seperti pengujian data waktu antar kedatangan entity. Hasil pengolahan data waktu pengerjaan masing-masing entity dapat dilihat pada Tabel 3 dan Tabel 4.

Berdasarkan model konseptual real system, selanjutnya dilakukan perancangan model simulasi dengan menggunakan aplikasi perangkat lunak simulasi Arena 3.0. Model real system Departemen Injection PT "X" ditunjukkan pada Gambar 3.

Perancangan sistem simulasi akan menghasilkan output yang dapat menunjukan tingkat performansi sistem. Kriteria performansi sistem ditunjukkan pada Tabel 5.

Variabel keputusan model ini akan lebih banyak ditetapkan pada model simulasi alternatif perbaikan untuk kemudian dibandingkan, skenario mana yang menghasilkan performansi terbaik bagi sistem. Variabel-variabel keputusan yang digunakan dalam penelitian ini adalah jumlah server yaitu ditambah satu teknisi pada server-1 dan perubahan sistem kerja tanpa adanya penambahan jumlah teknisi.

\section{Replikasi}

Jumlah replikasi yang dilakukan adalah sebanyak $n$ replikasi tergantung standar deviasi dan absolute error. Tabel 6 merupakan output dari 10 kali replikasi awal.

$$
\begin{aligned}
e & =\frac{\left(t \frac{\alpha}{2} \cdot R-1\right) \cdot S}{\sqrt{R}}=\frac{2,262 \cdot 6,6072}{\sqrt{10}} \\
& =4,726203 \\
n & =\left[\frac{\left(z \frac{\alpha}{2}\right) \cdot s}{e}\right]^{2}=\left(\frac{1,96 \cdot 6,6072}{4,726203}\right)^{2} \\
& =7,508046 \approx 8
\end{aligned}
$$

Jadi replikasi yang harus dilakukan adalah sebanyak 8 kali. Proses validasi model dilakukan untuk menentukan apakah model dapat mencerminkan sistem yang sesungguhnya atau tidak. Hal ini sangat penting karena tujuan dari membuat model ini adalah agar model tersebut dapat mencerminkan sistem sesungguhnya. Uji validasi ini dilakukan dengan membandingkan output hasil simulasi dengan output real system. Yang digunakan sebagai tolak ukur di sini adalah jumlah order yang diselesaikan tiap minggu.
Tabel 7 menunjukkan perbandingan output simulasi dan output real system.

Tabel 6. Output 10 replikasi

\begin{tabular}{ccc}
\hline No & Replikasi & Output \\
\hline 1 & 1 & 39 \\
2 & 2 & 32 \\
3 & 3 & 45 \\
4 & 4 & 41 \\
5 & 5 & 40 \\
6 & 6 & 26 \\
7 & 7 & 42 \\
8 & 8 & 29 \\
9 & 9 & 45 \\
10 & 10 & 40 \\
\hline \multicolumn{3}{c}{ S } \\
\hline
\end{tabular}

Tabel 7. Perbandingan output simulasi dan real

\begin{tabular}{ccc}
\multicolumn{3}{c}{ system } \\
\hline No & Real system & Simulasi \\
\hline 1 & 33 & 39 \\
2 & 37 & 33 \\
3 & 37 & 26 \\
4 & 29 & 36 \\
5 & 31 & 34 \\
6 & 39 & 34 \\
7 & 28 & 29 \\
8 & 27 & 32 \\
\hline
\end{tabular}

Model akan dijalankan selama 1 tahun yang diasumsikan terdapat 52 minggu dalam 1 tahun, dalam 1 minggu, terdapat 6 hari kerja yang artinya ada 2880 menit dalam 1 minggu. Jadi model simulasi akan dirunning sepanjang $2880 \mathrm{x}$ 52 sebanyak 8 kali. Tabel 8 menunjukan performansi dari real system.

Langkah selanjutnya adalah melakukan eksperimen dengan model simulasi untuk mendapatkan waktu mesin menunggu perbaikan yang minimal. Berdasarkan existing condition, dimana adanya mesin menunggu perbaikan terlalu lama, maka skenario perbaikan yang direkomendasikan lebih mengutamakan pengurangan waktu menunggu. Skenario ini dijadikan perbandingan dengan skenario awal untuk mencari performansi yang paling baik berdasarkan kriteria-kriteria performansi yang telah diuraikan di atas. 


\section{Skenario perbaikan real system}

Skenario perbaikan 1 berorientasi dengan menambah jumlah teknisi pada server-1 sehingga menjadi 4 orang teknisi seperti yang telah diusulkan oleh perusahaan. Tabel 9 menunjukan performansi dari skenario perbaikan 1 .

Skenario perbaikan 2 ini berorientasi pada perubahan sistem yaitu dengan menjadikan server-2 dan server-1 menjadi satu server pada pengerjaan setting, perbaikan air pendingin, dan perbaikan elektronik. Hal ini bisa dilakukan karena pengerjaan setting dan perbaikan pendingin tidak termasuk pekerjaan kasar sehingga server-2 bisa dimasukan. Server-1 juga bisa dibebani dengan pengerjaan elektronik karena resiko dari pengerjaan elektronik sangat kecil dan hal ini juga bisa meningkatkan kemampuan server-1 pada pekerjaan penyetingan.
Perubahan juga terjadi pada penanganan entity jenis kerusakan sehingga server-2 langsung turun tangan tanpa menunggu penanganan pertama dari server-1. Tabel 10 menunjukkan performansi skenario perbaikan 2. Tabel 11 menunjukkan perbandingan dari ketiga hasil model simulasi tersebut. Perbandingan performansi masingmasing model juga dapat dilihat pada Gambar 6 .

Gambar 6 memperlihatkan bahwa real system lebih baik dari pada kedua skenario perbaikan hanya pada utilitas server. Namun dari segala parameter yang dilakukan, kedua skenario perbaikan lebih baik. Pada grafik juga terlihat bahwa skenario perbaikan 1 lebih baik hanya pada waktu maksimal menunggu pada server-1 namun jika diukur dari parameter yang lain, skenario perbaikan 2 lebih baik.

Tabel 8. Performansi real system

\begin{tabular}{cccccccccccc}
\hline \multirow{2}{*}{ No. } & Kriteria & \multicolumn{1}{c}{ Replikasi } & \multicolumn{1}{c}{ Rata- } & \multirow{2}{*}{ Satuan } \\
\cline { 3 - 12 } & performansi & 1 & 2 & 3 & 4 & 5 & 6 & 7 & 8 & Rata & $\%$ \\
\hline 1 & Utilitas & 25 & 25 & 25 & 24 & 25 & 24 & 25 & 25 & 24,75 & $\%$ \\
2 & Waktu proses & 91 & 91 & 94 & 92 & 92 & 94 & 95 & 95 & 93 & menit \\
3 & max.diserver 1 & 121 & 172 & 213 & 186 & 184 & 212 & 155 & 230 & 184,1 & menit \\
4 & max.diserver 2 & 416 & 301 & 1072 & 860 & 372 & 680 & 526 & 541 & 596 & menit \\
\hline
\end{tabular}

Tabel 9. Performansi skenario perbaikan 1

\begin{tabular}{|c|c|c|c|c|c|c|c|c|c|c|c|}
\hline \multirow{2}{*}{ No. } & \multirow{2}{*}{$\begin{array}{c}\text { Kriteria } \\
\text { performansi }\end{array}$} & \multicolumn{8}{|c|}{ Replikasi } & \multirow{2}{*}{$\begin{array}{l}\text { Rata- } \\
\text { Rata }\end{array}$} & \multirow{2}{*}{ Satuar } \\
\hline & & 1 & 2 & 3 & 4 & 5 & 6 & 7 & 8 & & \\
\hline 1 & utilitas & 20 & 20 & 20 & 20 & 20 & 19 & 20 & 19 & 19,75 & $\%$ \\
\hline 2 & waktu proses & 96 & 93 & 90 & 89 & 89 & 90 & 91 & 92 & 91,1 & menit \\
\hline 3 & max.diserver 1 & 44 & 35 & 4 & 81 & 61 & 30 & 60 & 53 & 45,9 & menit \\
\hline 4 & max.diserver 2 & 489 & 387 & 374 & 479 & 556 & 611 & 697 & 477 & 508,67 & menit \\
\hline
\end{tabular}

Tabel 10. Performansi skenario perbaikan 2

\begin{tabular}{cccccccccccc}
\hline \multirow{2}{*}{ No. } & Kriteria & \multicolumn{1}{c}{ Replikasi } & Rata- & \multirow{2}{*}{ Satuan } \\
\cline { 3 - 11 } & performansi & 1 & 2 & 3 & 4 & 5 & 6 & 7 & 8 & Rata & \\
\hline 1 & utilitas & 24 & 24 & 23 & 23 & 24 & 23 & 23 & 23 & 23,38 & $\%$ \\
2 & waktu proses & 85 & 85 & 85 & 84 & 88 & 85 & 87 & 83 & 85,25 & menit \\
3 & max.diserver 1 & 118 & 95 & 290 & 54 & 108 & 74 & 55 & 62 & 107 & menit \\
4 & max.diserver 2 & 298 & 294 & 265 & 415 & 786 & 243 & 417 & 729 & 430,9 & menit \\
\hline
\end{tabular}

Tabel 11. Perbandingan performansi

\begin{tabular}{cccccc}
\hline \multirow{2}{*}{ No. } & Kriteria & \multicolumn{3}{c}{ Rata-rata } & \multirow{2}{*}{ Satuan } \\
\cline { 3 - 5 } & performansi & Real sistem & skenario 1 & skenario 2 & \\
\hline 1 & utilitas & 24,75 & 19,75 & 23,375 & $\%$ \\
2 & waktu proses & 93 & 90,875 & 85,25 & Menit \\
3 & max.diserver 1 & 184,125 & 45,625 & 107 & Menit \\
4 & max.diserver 2 & 596 & 508,5 & 430,875 & menit \\
\hline
\end{tabular}


Tabel 12. Perubahan performansi

\begin{tabular}{cccccccc}
\hline \multirow{2}{*}{ No. } & Kriteria & \multicolumn{2}{c}{ Real Vs sknr1 } & \multicolumn{2}{c}{ Real Vs sknr2 } & \multicolumn{2}{c}{ Sknr1 Vs sknr2 } \\
\cline { 3 - 7 } & performansi & Perubahan & $\%$ & perubahan & $\%$ & Perubahan & $\%$ \\
\hline 1 & utilitas & Ya & $-20,2$ & Ya & $-5,56$ & Ya & 18,354 \\
2 & waktu proses & Tidak & - & Ya & $-8,33$ & Ya & $-6,19$ \\
3 & max.diserver 1 & Ya & $-75,22$ & Ya & $-41,9$ & Tidak & - \\
4 & max.diserver 2 & Tidak & - & Tidak & - & Tidak & - \\
\hline
\end{tabular}

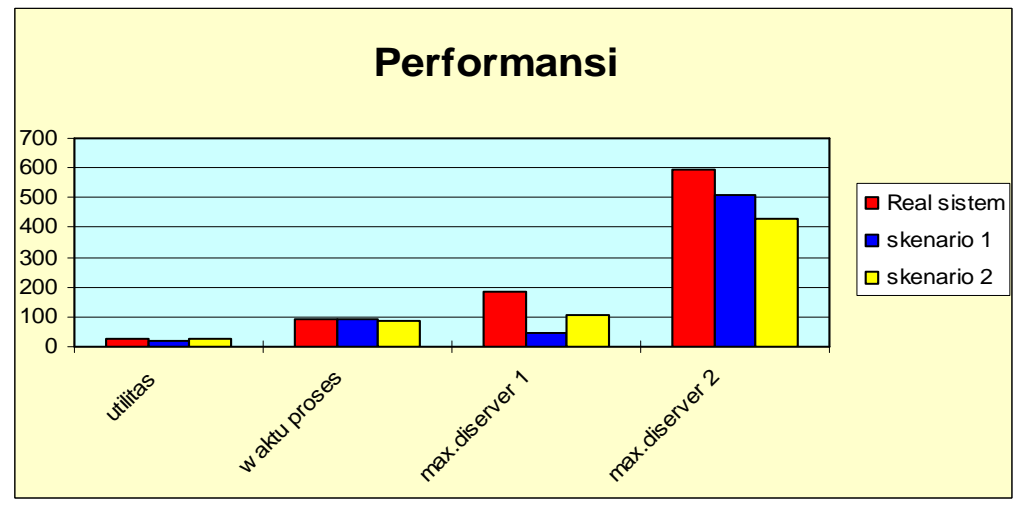

Gambar 6. Grafik perbandingan performansi sistem

Perbandingan performansi sistem juga dilakukan melalui uji hipotesa. Tabel 12 menunjukan perubahan performansi sistem berdasarkan uji kesamaan data rata-rata.

Jika skenario perbaikan 1 diterapkan menggantikan real system, maka dampak perubahan yang dihasilkan adalah: (1) tingkat kesibukan teknisi turun hingga 20,2\%, (2) tidak ada perubahan waktu proses, (3) waktu maksimal menunggu di server-1 turun hingga 75,22\%, dan (4) tidak ada perubahan waktu maksimal menunggu pada server-1.

Bila skenario 1 diterapkan, maka perusahaan harus mengeluarkan biaya untuk gaji satu teknisi lagi. Sedangkan jika skenario 2 diterapkan menggantikan real system, maka dampak perubahan yang dihasilkan adalah: (1) tingkat kesibukan teknisi turun hingga 5,56\%, (2) mampu menekan waktu proses hingga $8,33 \%$, (3) waktu maksimal menunggu di server-1 turun $41,9 \%$, (4) tidak ada perubahan waktu maksimal menunggu pada server -2 , dan (5) tidak ada perubahan waktu maksimal menunggu pada server-1 bila dibandingkan dengan skenario perbaikan 1.

\section{SIMPULAN}

Berdasarkan analisis hasil simulasi, maka dapat disimpulkan bahwa:

1. Penambahan 1 orang teknisi, maka yang diuntungkan adalah server-1 karena tingkat kesibukan teknisi turun hingga 20,2\% namun tidak bisa menekan waktu proses pada sistem.

2. Perusahaan akan mampu menekan waktu proses hingga 8,33\% karena turunya waktu menunggu bila perusahaan tidak jadi menambah 1 orang teknisi namun merubah sistem yang berlaku yaitu menyilangkan tugas server-1 dengan server-2 pada kegiatan yang bisa disilangkan.

3. Secara visual pada waktu maksimal menunggu pada sever-1, skenario 1 lebih unggul dari skenario 2, namun setelah dilakukan uji kesamaan data rata-rata menunjukkan bahwa kedua rata-rata populasi adalah sama

4. Saran perbaikan sistem yang sekiranya dapat bermanfaat bagi departemen injection PT. "X" adalah agar tidak menambah jumlah teknisi. Namun perlu merubah sistem kerja dari teknisi tersebut yaitu menyilangkan tugas teknisi yang termasuk dalam server-1 dengan tugas teknisi yang termasuk dalam server-2. 


\section{DAFTAR PUSTAKA}

Kelton, W.D.; Sadowski, R. P.; Sadowski, D. A. (2003). Simulation with Arena. 3rd edition . Mc Grow Hill Book Companies.

Liong, C-Y.; Loo, C.S.E. (2009). 'A simulation study of warehouse loading and unloading systems using ARENA (Kajian simulasi ke atas sistem pemuatan dan pemunggahan gudang menggunakan ARENA)'. Journal of Quality Measurement and Analysis (JQMA), Vol. 5 (2), pp.45-56.

Suryani, E. (2006). Pemodelan \& Simulasi. Yogyakarta: CV. Graha Ilmu.

Sulistyono, A.A.B.; Sudiarso, A. (2013). Simulasi Teknik Penanganan Material Sistem Produksi Secara Manual dan Otomatis Berbasis Automatic Guided Vehicle (AGV)'. Simposium Nasional RAPI XII - 2013, ISSN 1412-9612, Fakultas Teknik Universitas Muhammadiyah Surakarta.

Sharma, P. 2015. Discrete-event simulation. International Journal of Scientific \& Technology Research, Vol. 4 (4), pp. 136-140.

Wahyani, W.; Ahmad, N.H. (2009). Analisis Bottle Neck dengan Pendekatan Simulasi Arena pada Produk Sarung Tenun Ikat Tradisional. Program Studi Teknik Industri, Fakultas Teknologi Industri, Institut Teknologi Adhi Tama Surabaya.

Wibowo, A.: Ramadian, D. (2010). 'Model simulasi kinerja produksi teh untuk minimisasi work-in-process.' Jurnal Optimasi Sistem Industri, Vol. 9 (1), pp. 7-12. 